\title{
HAKEKAT MISI YESUS KEPADA PARA MURID DALAM MATIUS 10:1-15 SEBAGAI DASAR MISI GEREJA DALAM MENJALANKAN MISI ALLAH
}

\section{Yohanis Udju Rohi}

\section{PENDAHULUAN}

Kedatangan Yesus ke dunia memiliki misi yang jelas, di mana Yesus datang untuk menyatakan kasih Allah yang menyelamatkan. Gereja sebagai tubuh Kristus bukan hanya diselamatkan tetapi juga dipanggil untuk menjadi pembawa berita keselamatan bagi orang yang belum percaya kepada Tuhan Yesus sebagai Tuhan dan Juruselamat pribadinya. Oleh karena itu gereja harus memiliki dasar pemahaman dan praktek misi yang benar sesuai dengan misi Yesus yang juga adalah misi Allah.

\section{A. HAKEKAT MISI YESUS KEPADA PARA MURID DALAM \\ MATIUS 10:1-15}

\section{Peranan Yesus Dalam Misi-Nya (ayat 1-5)}

\section{a. Yesus sebagai inisiator (caller) misi (ayat 1a)}

Pelayanan misi Yesus adalah prakarsa Yesus sendiri, di mana Yesus dapat disebut sebagai inisiator sekaligus sebagai pelaku misi. Hal ini nampak dalam frasa: "Yesus memanggil." Dalam terjemahan NIV menuliskan "He called"1, dapat berarti: Dia memanggil atau meneriakkan. ${ }^{2}$ Sedangkan terjemahan bahasa Yunani Kai Proska le, samenoj ${ }^{3}$ yang secara literal dapat berarti "adapun setelah memanggil datang". Kata "proskale, saj" berasal dari kata dasar "proskale, w" yang memiliki pengertian: memanggil datang, memanggil ke depan, memanggil. 5 Kata "proskale, saj"

${ }^{1}$ Hasan Susanto, Perjanjian Baru Interlinear, Yunani-Indonesia dan Konkordansi (PBIK) Jilid I, (Jakarta: Lembaga Alkitab Indonesia, 2006),47

2 John M. Echols dan Hassan Shadily, Kamus Inggris Indonesia, (Jakarta: PT Gramesia, 1997), 94

${ }^{3}$ Hasan Susanto, Perjanjian Baru Interlinear....., jilid I, 47

${ }^{4}$ Ibid., 47

${ }^{5}$ Ibid, 677 
merupakan kata kerja Aorist arah Medium Partisif maskulin tunggal. ${ }^{6}$ Kata kerja Aorist menekankan bahwa memanggil adalah suatu tindakan yang hanya satu kali saja dilakukan pada masa lampau, arah medium menyatakan bahwa memanggil merupakan suatu tindakan yang refleksif, juga dapat menekankan suatu kesungguhan dalam memanggil. Partisip maskulin tunggal sebagai nominative menyatakan bahwa subjek bertindak untuk memanggil. Subjek dalam teks Yunani tidak disebutkan dengan jelas, namun jika dilihat perikop sebelumnya (9:35) dan ayat sesudahnya (10:5), maka jelaslah bahwa subjek yang dimaksud dalam ayat ini adalah Yesus sendiri.

Dalam konteks teks ini, dapat dipahami bahwa memanggil adalah tindakan yang telah dilakukan oleh Yesus. Inisiatif dan tindakan untuk memanggil dari dan oleh Yesus sendiri, secara refleksif bukan karena didorong atau dipengaruhi oleh sesuatu di luar diri-Nya, termasuk oleh para murid. Tindakan itu dilakukan dengan sungguh-sungguh sebagai bentuk keseriusan Yesus dalam kegiatan misi. Kehadiran dan keterlibatan para murid dalam pelayanan misi semata-mata dimungkinkan hanya oleh anugerah Tuhan Yesus yang memanggil. Dasar panggilan misi para murid berdasarkan pada Yesus sebagai inisiator misi.

\section{b. Yesus sebagai dinamisator (authorial) misi (ayat 1b)}

Yesus bukan hanya memanggil, namun sebelum mengutus para murid, Yesus juga memperlengkapi mereka dengan kuasa. Hal ini dapat terbaca dalam frasa "Ia memberi kuasa kepada mereka", menurut terjemahan baru Lembaga Alkitab Indonesia (LAI). ${ }^{7}$ Dalam bahasa Yunani e; dwken eivj auvtou.j evxousi, an yang secara literal dapat berarti: "Ia memberi kepada mereka kuasa". ${ }^{8}$ Kata $e$; dwken berasal dari kata dasar didwmi yang berarti memberikan, mengijinkan, membagi-bagikan, mengirim, mempercayakan, mengeluarkan, menaruh, mengenakan, mengadakan, membuat, menyerahkan. ${ }^{9}$ Kata ini dalam bentuk kata kerja orang ketiga tunggal, aorist, aktiv, indikatif. ${ }^{10} \mathrm{Hal}$ itu mengindikasikan bahwa Yesus yang

\footnotetext{
${ }^{6}$ Hasan Susanto, Perjanjian Baru Interlinear....., jilid I, 47

${ }^{7}$ Ibid, 47

${ }^{8}$ Ibid., 47

${ }^{9}$ Hasan Susanto, Perjanjian Baru Interlinear....., Jilid II..., 206

${ }^{10}$ Hasan Susanto, Perjanjian Baru Interlinear....., Jilid I..., 47
} 
telah bertindak memberikan kuasa kepada para murid pada masa lampau secara factual (sungguh-sungguh pernah terjadi).

Kuasa yang diberikan Yesus kepada para murid dalam bahasa Yunani evxousi, an yang berarti: kuasa, hak, tugas, kekuatan, kekuasaan, pengontrolan, kuasa supernatural, penguasa, penguasa supernatural, pemerintah, wilayah yang dikuasai, media yang memberi kuasa, tanda martabat, tanda tunduk kepada kuasa. ${ }^{11}$ Sedangkan dalam terjemahan NIV menuliskan"authority"12 yang berarti: wibawa, hak untuk bertindak, ahli, wewenang, sumber. ${ }^{13}$ Pasaribu, menuliskan, bahwa: "Seorang utusan bertindak dengan penuh kuasa untuk menyampaikan berita dari si pengutus atau si pemberi kuasa dan Yesus memberi kuasa kepada para murid sama seperti kuasa Yesus sebab kuasa itu berasal dari Yesus". ${ }^{14}$

Sebelum para murid terlibat dalam pelayanan misi, mereka sudah terlebih dahulu diperlengkapi dengan kuasa, kekuasaan supernatural, kekuatan, pengontrolan wibawa oleh Yesus. Kuasa yang diberikan Yesus kepada para murid menjadikan mereka mampu melakukan hal-hal yang supernatural seperti mengusir roh-roh jahat, menyembuhkan orang sakit, melenyapkan segala penyakit dan kelemahan sebagaimana terdapat dalam ayat 7 dan 8 . Kemampuan dan keberanian para murid dalam bermisi berasal dan bergantung pada Yesus sebagai sumber kuasa misi.

\section{c. Yesus sebagai delegator (sender) misi (ayat 5)}

Setelah Yesus memanggil dan memperlengkapi para murid dengan kuasa, kemudian Yesus mengutus para murid untuk bermisi. Hal tersebut dijelaskan dalam frasa "diutus oleh Yesus" menurut terjemahan baru Lembaga Alkitab Indonesia (LAI). ${ }^{15}$ Dalam terjemahan NIV “Jesus sent out" yang berarti: Yesus mengedarkan, memancarkan, menyuruh. ${ }^{16}$ Dalam bahasa Yunani kata avpe, steilen dari kata dasar avposte, $11 \mathrm{w}$ yang berarti: mengirim. ${ }^{17}$ Kata itu dalam bentuk kata kerja orang ketiga tunggal aorist aktiv

${ }^{11}$ Hasan Susanto, Perjanjian Baru Interlinear....., Jilid II..., 289

${ }^{12}$ Hasan Susanto, Perjanjian Baru Interlinear....., Jilid I..., 47

${ }^{13}$ John M. Echols dan Hassan Shadily, Kamus Inggris Indonesia ...,46

14 Marulak Pasaribu, Injil Sinoptik, Yesus Yang Diberitakan Dalam Injil Matius, Markus \& Lukas, (Batu: Departemen Literatur YPPII,), 172

${ }^{15}$ Hasan Susanto, Perjanjian Baru Interlinear....., Jilid I..., 47

${ }^{16}$ John M. Echols dan Hassan Shadily, Kamus Inggris Indonesia ..., 513

${ }^{17}$ Hasan Susanto, Perjanjian Baru Interlinear....., Jilid II..., 105 
indikatif. ${ }^{18}$ Hal itu mengindikasikan bahwa Yesus yang telah bertindak mengutus para murid pada masa lampau secara factual (sungguh-sungguh pernah terjadi). Yesus benar-benar telah mengutus para murid untuk pelayanan misi. Misi adalah misi Yesus yang mengutus, para murid hanya sebagai utusan. Sebagai utusan harus bertindak atas nama dan menyampaikan berita dari Yesus yang mengutus. Keterlibatan dan kelayakan para murid dalam misi hanya dimungkinkan oleh Yesus yang mengutus.

\section{d. Yesus sebagai instructor misi (ayat 5)}

Yesus memberikan arah yang jelas kepada para murid untuk bermisi dengan pesan (petunjuk) yang jelas. Hal ini terlihat pada frasa "Ia berpesan kepada mereka" menurut terjemahan baru Lembaga Alkitab Indonesia (LAI) ${ }^{19}$ menyatakan bahwa dalam waktu yang bersamaan ketika Yesus memanggil, memperlengkapi dengan kuasa, dan mengutus, Yesus juga menjadi instruktur misi bagi para murid. Kata berpesan menurut terjemahan NIV "following instructions" yang berarti: menyertakan pengajaranpengajaran, perintah-perintah. ${ }^{20}$ Dalam bahasa Yunaninya kata parh, ggeilavj dari kata dasar parh, ggeillw yang berarti: memberi perintah, berpesan, menyuruh. ${ }^{21}$ Kata ini merupakan kata kerja aorist aktiv participle maskulin singular nominative. ${ }^{22}$ Artinya Yesus telah terlebih dahulu menginstruksikan atau memberikan pengajaran-pengajaran atau perintahperintah sebagai pedoman bagi para murid sebelum bermisi. Jadi pelayanan dan pelaksanaan misi para murid harus berdasarkan pengajaran-pengajaran atau perintah-perintah Yesus. Pengajaran-pengajaran atau perintah-perintah itu akan dikaji dan dipahami dalam pembahasan berikutnya, tentang tanggung jawab para murid sebagai agen tunggal misi Yesus dalam bermisi berdasarkan teks Injil Matius 10:1-15.

\section{e. Rangkuman}

Misi Yesus tidak dapat dilepaskan dari peran Yesus sendiri sebagaimana terdapat dalam Matius 10:1-15. Yesus adalah inisiator misi,

\footnotetext{
${ }^{18}$ Hasan Susanto, Perjanjian Baru Interlinear....., Jilid I..., 48

${ }^{19}$ Hasan Susanto, Perjanjian Baru Interlinear....., Jilid I..., 47

${ }^{20}$ John M. Echols dan Hassan Shadily, Kamus Inggris Indonesia ...,325

${ }^{21}$ Hasan Susanto, Perjanjian Baru Interlinear....., Jilid II..., 604

${ }^{22}$ Hasan Susanto, Perjanjian Baru Interlinear....., Jilid I..., 48
} 
dimana Yesus sendiri berinisiatif dan bertindak memamggil para murid. Kehadiran dan keterlibatan para murid dalam pelayanan misi semata-mata dimungkinkan hanya oleh anugerah Tuhan Yesus yang memanggil. Sebagai dinamisator (authorial) misi, Yesus memberi kuasa kepada para murid untuk bermisi, kemudian Yesus juga bertindak sebagai delegator (sender) misi, yang mengirim/mengutus para murid untuk bermisi, dalam waktu yang bersamaan, Yesus juga selaku instructor misi memberikan arah yang jelas melalui petunjuk-petunjuk yang harus dilakukan para murid dalam bermisi. Keempat hal tersebut di atas, menjadi pilar pelayanan misi para murid.

\section{Tanggung jawab Para murid sebagai agen tunggal misi Yesus dalam bermisi (ayat 6-8a)}

Dalam perikop ini nama kedua belas murid Yesus secara lengkap dituliskan, mereka ialah Simon yang disebut Petrus dan Andreas saudaranya, Yakobus anak Zebedeus dan Yohanes Saudaranya, Filipus dan Bartolomeus, Tomas dan Matius Pemungut Cukai, Yakobus anak Alfeus, dan Tadeus, Simon orang Zelot dan Yudas Iskariot yang mengkhianati Yesus (ayat 2). Para murid yang dipanggil, diberi kuasa, diutus dan diberikan instruksi oleh Yesus. Selain diperlengkapi,mereka juga diberikan tanggung jawab untuk bermisi, hal itu nampak pada pembahasan berikut ini, yakni:

\section{a. Para murid harus pergi (going) (ayat 6)}

Pada pembahasan ini para murid diperintahkan untuk pergi, hal itu nampak dalam frasa"pergilah" sebagaimana terjemahan baru Lembaga Alkitab Indonesia (LAI). ${ }^{23}$ Terjemahan NIV “go" yang berarti: pergi, berangkat. ${ }^{24}$ Sedangkan dalam terjemahan bahasa Yunani poreu, esqe dari kata poreuw yang berarti: pergi, berangkat, bepergian, berjalan, meneruskan, perjalanan, berlalu, hidup, meninggal. ${ }^{25}$ Kata poreu, esqe dalam bentuk kata kerja orang kedua jamak present middle imperative. ${ }^{26}$ "Pergi" adalah perintah Yesus, yang mana "pergi" berlaku sejak perintah diberikan (pada masa lampau) dan

\footnotetext{
${ }^{23}$ Hasan Susanto, Perjanjian Baru Interlinear....., Jilid I...,48

${ }^{24}$ John M. Echols dan Hassan Shadily, Kamus Inggris Indonesia ...,272

${ }^{25}$ Hasan Susanto, Perjanjian Baru Interlinear....., jilid I, 661

${ }^{26}$ Hasan Susanto, Perjanjian Baru Interlinear....., Jilid I...,48
} 
secara terus menerus, sekarang dan sampai pada masa yang akan datang. Hal ini dapat dipahami bahwa Yesus telah memerintahkan para murid untuk pergi melaksanakan misi-Nya bukan hanya pada saat perintah diberikan, namun dilakukan secara berkesinambungan selama masa hidup para murid. Kerinduan Yesus supaya para murid menjadi pelaksana misi yang penuh antusias dan proaktif selama mereka hidup.

\section{b. Para murid harus memberitakan (preaching) (ayat 7)}

Yesus memerintahkan para murid untuk pergi dengan tujuan misi yang sangat jelas. seperti yang nampak dalam terjemahan baru Lembaga Alkitab Indonesia (LAI) ${ }^{27}$ dari frasa "... dan beritakanlah: kerajaan Sorga sudah dekat" Menurut terjemahan NIV "As you go, preach this massage: "The kingdom of heaven is near". 28 Dalam ayat 7 kata "pergi" ditulis bukan dalam bentuk perintah, melainkan bentuk partisip dengan arah medium. Bentuk ini menyatakan bahwa pergi merupakan tindakan yang bersamaan dengan kata kerja pokok dalam ayat 7, yakni "memberitakan." Terjemahan NIV "preach" berarti: mengajarkan, berkhotbah, menasihati. ${ }^{29}$ Sedangkan dalam bahasa Yunani kata beritakanlah "keruvssete" 30 yang berarti: memberitahukan, menceritakan, berkhotbah, memuji secara terbuka. ${ }^{31}$ Kata "keruvssete" merupakan kata kerja orang kedua jamak, presen, aktif, imperative. ${ }^{32}$ Dapat dipahami bahwa perintah Yesus untuk memberitakan harus dilakukan secara terus menerus, yakni pada saat perintah itu diberikan sampai selama hidup mereka. Yesus memerintahkan para murid untuk memberitahukan, menceritakan dan mengkhotbahkan tentang kerajaan Allah sudah dekat, harus dilakukan terus-menerus.

Isi berita misi yang disampaikan oleh para murid harus jelas, yang mana hal ini ditegaskan dengan kata le, gontej ${ }^{33}$ yang bentuknya sama dengan bentuk kata "pergi" dalam ayat ini, yaitu bentuk partisip namun dengan arah aktif. Artinya bahwa Kerajaan Sorga harus diberitakan dengan perkataan

\footnotetext{
${ }^{27}$ Hasan Susanto, Perjanjian Baru Interlinear....., Jilid I...,48

${ }^{28}$ Ibid.

${ }^{29}$ John M. Echols dan Hassan Shadily, Kamus Inggris Indonesia ...,442

${ }^{30}$ Hasan Susanto, Perjanjian Baru Interlinear....., Jilid I..., 48

${ }^{31}$ Hasan Susanto, Perjanjian Baru Interlinear....., Jilid II...,447

${ }^{32}$ Hasan Susanto, Perjanjian Baru Interlinear....., Jilid I...,48

${ }^{33}$ Ibid.
} 
atau proklamasi. Dalam terjemahan baru Lembaga Alkitab Indonesia (LAI) memakai istilah "Kerajaan Sorga" 34 dan dalam terjemahan NIV "The Kingdom of heaven". ${ }^{35}$ Dalam bahasa Yunani basilei, a tw/n ouvranw/n ${ }^{36}$ kata basilei, a memiliki pengertian: kuasa sebagai raja, kuasa kerajaan, (wilayah) kerajaan, kerajaan, kerajaan (Allah). ${ }^{37}$ Kata ouvranw/n berarti: langit, surga. ${ }^{38}$ Penggunaan istilah "kerajaan Surga" berkaitan dengan latar belakang dan tujuan penulisan Injil Matius yang dialamatkan kepada orang Yahudi, ${ }^{39}$ Penghindaran Matius terhadap penggunaan nama Allah dengan memakai kata Surga semata-mata mengingat pembacanya yang berlatar belakang Yahudi. Bagi orang Yahudi penggunaaan nama Allah itu bertentangan dengan hukum ketiga dari sepuluh hukum (Keluaran 20:7). ${ }^{40}$ Vine menjelaskan istilah kerajaan Surga, demikian:

"While, then, the sphere of the Kingdom of God and the Kingdom of Heaven are at times identical, yet the one term cannot be used indiscriminately for the other. In the "Kingdom of Heaven" (32 times in Matt.), heaven is in antithesis to earth, and the phrase is limited to the Kingdom in its earthly aspects for the time being, and is used only dispensationally and in connection with Israel...The Kingdom of Heaven is always the Kingdom of God, but the Kingdom of God is not limited to the Kingdom of Heaven, until in their final form, they become identical; e.g., Rev.11:15, RV; John 3:5; Rev.12:10." ${ }^{41}$

Frasa "sudah dekat" dalam terjemahan NIV "is near"42 yang berarti: dekat. ${ }^{43}$ Sedangkan dalam terjemahan bahasa Yunani h; ggiken ${ }^{44}$

\footnotetext{
${ }^{34}$ Hasan Susanto, Perjanjian Baru Interlinear....., Jilid I...,48

${ }^{35}$ Hasan Susanto, Perjanjian Baru Interlinear...... Jilid I, 48

${ }^{36}$ Ibid.

${ }^{37}$ Hasan Susanto, Perjanjian Baru Interlinear......, Jilid II...,144

${ }^{38}$ Ibid...,588

${ }^{39}$ Ola Tulluan, Introduksi Perjanjian Baru, (Batu: Departemen Literatur YPPII, tt), $35-36$

${ }^{40}$ Samuel Benyamin Hakh, Pemberitaan Tentang Yesus Menurut Injil-Injil Sinoptik, (Bandung: Jurnal Info Media, 2008), 42

${ }_{41}$ W.E. Vine, Vines Complete Expository Dictionary, (Amerika: Thomas Nelson Publishers, 1996), 345

${ }^{42}$ Hasan Susanto, Perjanjian Baru Interlinear....., Jilid I...,48
} 
dari kata e,ggi,zw yang berarti: mendekat, dekat. ${ }^{45}$ Hakh memberi pandangan sebagai berikut:

Di sini kita melihat bahwa istilah eggiken (=sudah dekat) (lihat juga Mat. 3:2; 10:7) membentuk suatu ketegangan antara masa kini dan masa depan. Pada satu pihak istilah itu menyatakan bahwa kerajaan itu sudah dekat, begitu dekat dalam pribadi Yesus sehingga kuasa kerajaan itu secara menentukan bertindih dengan atau dialami pada masa kini. namun pada pihak lain, istilah itu (eggeken) menyatakan bahwa pemenuhan kerajaan itu belum tiba, ia (pemenuhan kerajaan itu) masih di depan karena Allah belum secara penuh menyatakan pemerintahan-Nya. ${ }^{46}$

Kerajaan Allah sudah dekat artinya: Dalam diri Yesus kerajaan itu telah hadir secara radikal. Arah dan tujuan dari proklamasi Injil adalah bahwa Allah dalam pemerintahan-Nya sedang datang mendekat kepada manusia dalam pribadi Yesus Kristus. Jadi penekanan pemberitaan yang harus diberitakan oleh para murid dalam pelayanan misi mereka ialah: tentang Yesus sendiri sebagai wujud kehadiran kerajaan Allah membebaskan manusia dari kuasa dosa dan kuasa iblis.

\section{c. Para murid harus Menyembuhkan (Healing) (ayat 8a)}

Pelayanan misi yang harus dilakukan oleh para murid bukan hanya misi pemberitaan atau proklamasi saja, karena dalam ayat 8a Yesus memerintahkan para murid untuk melakukan pelayan misi penyembuhan orang sakit. Hal itu nampak dalam Frasa "sembuhkanlah orang sakit". 47 Dalam terjemahan NIV "Heal" yang berarti: menyembuhkan. ${ }^{48}$ Sedangkan dalam terjemahan bahasa Yunani qerapeu,ete ${ }^{49}$ dari kata qerapeuw yang berarti:

\footnotetext{
${ }^{43}$ John M. Echols dan Hassan Shadily, Kamus Inggris Indonesia ...,391

44 Hasan Susanto, Perjanjian Baru Interlinear....., Jilid I...,48

${ }^{45}$ Hasan Susanto, Perjanjian Baru Interlinear....., Jilid II, 233

${ }^{46}$ Samuel Benyamin Hakh, Pemberitaan Tentang Yesus Menurut Injil-Injil Sinoptik..,44

47 Hasan Susanto, Perjanjian Baru Interlinear....., Jilid , 48

${ }^{48}$ John M. Echols dan Hassan Shadily, Kamus Inggris Indonesia ..., 293

${ }^{49}$ Hasan Susanto, Perjanjian Baru Interlinear....., Jilid I...,48
} 
melayani, menyembuhkan. ${ }^{50}$ Merupakan kata kerja orang kedua jamak, presen, aktif, imperative. ${ }^{51}$ Dapat dipahami bahwa pelayanan misi menyembuhkan orang sakit adalah suatu perintah yang harus dilakukan, karena bukan suatu pilihan dan harus segera dilakukan sesudah perintah itu diberikan, selain dilakukan saat itu, juga harus berlangsung terus-menerus dalam waktu di kemudian hari.

Frasa "orang sakit" dalam terjemahan NIV " the sick" yang berarti: orang-orang yang sakit. ${ }^{52}$ Dalam terjemahan bahasa Yunani vsqenou/ntaj dari kata asqenew yang berarti: menjadi lemah, atau tidak berdaya, (termasuk dalam pengertian ekonomi, rasa takut, moral, atau agama), menderita penyakit. ${ }^{53}$ Bila dipahami dari berbagai keadaan orang yang harus dilayani berdasarkan kata asteneo, maka pelayanan penyembuhan yang Yesus maksudkan bagi para murid ialah bersifat holistik. Jadi bentuk dan pendekatan pelayanan misi para murid bersifat holostik berdasarkan misi Yesus.

\section{d. Para Murid harus membangkitkan (Raising) (ayat 8b)}

Misi membangkitkan yang diperintahkan Yesus kepada para murid pada pembahasan ini ialah membangkitkan orang mati sebagai mana tertulis dalam terjemahan baru Lembaga Alkitab Indonesia (LAI). ${ }^{54}$ Dalam terjemahan NIV memakai kata "raise the dead"55 yang dapat berarti hidupkanlah yang mati. Sedangkan dalam terjemahan bahasa Yunani nekrou.j evgei, rete ${ }^{56}$ kata nekrou.j dari kata dasar nekro.j yang berarti: mati, yang tidak berguna. ${ }^{57}$ Sedangkan kata evgei, rete dari kata dasar evgei, rw yang berarti: membangunkan (orang tidur), bangun (dari tidur), membangkitkan (agar berdiri), bangkit (berdiri), membangkitkan (orang mati), mendirikan kembali, menjadikan, tampil. ${ }^{58}$ Kata evgei, rete merupakan

\footnotetext{
${ }^{50}$ Hasan Susanto, Perjanjian Baru Interlinear....., Jilid II..., 71

${ }^{51}$ Hasan Susanto, Perjanjian Baru Interlinear....., Jilid I, 48

52 John M. Echols dan Hassan Shadily, Kamus Inggris Indonesia..., 525

53 Hasan Susanto, Perjanjian Baru Interlinear....., Jilid II, 123

${ }^{54}$ Hasan Susanto, Perjanjian Baru Interlinear......, Jilid I, 48

55 Ibid.

56 Ibid

${ }^{57}$ Hasan Susanto, Perjanjian Baru Interlinear....., Jilid I, 536

58 Ibid., 234
} 
kata kerja orang kedua jamak presen aktif imperative. ${ }^{59}$ Dapat dipahami bahwa misi para murid untuk membangkitkan orang mati adalah suatu perintah yang harus dilakukan segera sesudah perintah itu diberikan dan harus berlangsung terus menerus, sebagai suatu pola pelayanan misi yang berkelanjutan. Dengan demikian membangkitkan orang mati tidak boleh dipahami secara sempit, karena kematian yang dimaksud dalam teks ini bukan hanya kematian secara fisik (tubuh), tetapi juga kematian secara roh (rohnya mati, tubuhnya masih hidup).

Misi membangkitkan orang mati adalah merupakan salah satu mujizat dalam PB. ${ }^{60}$ Tujuan mujizat ialah untuk menyatakan bahwa Yesus adalah Tuhan atas alam (Luk.8:41-56) dan sebagai bukti bahwa Kerajaan Allah telah hadir dalam pelayanan-Nya (Mat.11:2-5; 12:28). Mujizat menjadi suatu tanda bahwa keselamatan telah hadir dalam kuasa Allah, sebab orang mati telah dibangkitkan dan setan-setan telah diikat, orang sakit disembuhkan. ${ }^{61}$ Tujuan mujizat bukan sekedar membangkitkan orang yang telah mati saja, tetapi bertujuan misiologi dan soteriologi. Jadi pelayanan misi para murid untuk membangkitkan orang mati harus berdasarkan pada tujuan misi Yesus yang bersifat misiologis dan soteriologis.

\section{e. Para murid harus mentahirkan (Cleansing) (ayat 8c)}

Misi mentahirkan merupakan bentuk misi Yesus kepada para murid, hal tersebut nampak dalam frasa, "tahirkanlah orang kusta" dalam terjemahan baru Lembaga Alkitab Indonesia (LAI). ${ }^{62}$ Dalam terjemahan NIV memakai kata "cleanse those who hev leprosy" 63 dalam terjemahan bahasa Yunani leprou.j kaqari, zete ${ }^{64}$ kata leprou.j dari kata dasar lepro.j yang berarti: yang sakit kusta. ${ }^{65}$ Sedangkan kata kaqari, zete dari kata dasar kaqari, zw yang berarti: membersihkan, mentahirkan, melenyapkan,

59 Hasan Susanto, Perjanjian Baru Interlinear......, Jilid I, 48

${ }^{60}$ J. D. Douglas, Ensiklopedia Alkitab Masa Kini, (Jakarta: Yayasan Komunikasi Bina Kasih, 2005), 96

${ }^{61}$ Marulak Pasaribu, Injil Sinoptik, (Batu: Departemen Literatur YPPII, tt), 147

${ }^{62}$ Hasan Susanto, Perjanjian Baru Interlinear....., Jilid I, 48

${ }^{63} \mathrm{Ibid}$

${ }^{64}$ Ibid

${ }^{65}$ Hasan Susanto, Perjanjian Baru Interlinear....., Jilid II, 485 
menyatakan bersih, menyucikan. ${ }^{66}$ Berbentuk kata kerja orang ke dua jamak presen aktif imperative. ${ }^{67}$ Dapat dimengerti bahwa misi mentahirkan orang kusta adalah misi yang harus dilakukan oleh para murid karena merupakan suatu perintah dan segera dilakukan sesudah menerima perintah, serta berlangsung terus-menerus dalam pelayanan di kemudian hari. Dalam PL orang yang mengalami penyakit kusta dianggap najis dan dikucilkan dari tengah masyarakat. ${ }^{68}$ Penjangkauan para murid dalam misi berdasarkan hakekat misi Yesus, termasuk kepada orang yang termarjinalkan dalam masyarakat.

\section{f. Para murid harus Mengusir (Driving Out) (ayat 8d)}

Selain misi pemberitaan atau proklamasi dan penyembuhan, Yesus juga memerintahkan dan mengarahkan para murid untuk melakukan pelayanan misi pengusiran setan-setan, hal itu nampak dalam frasa "usirlah setan-setan" dalam terjemahan baru Lembaga Alkitab Indonesia (LAI). ${ }^{69}$ Sedangkan dalam terjemahan NIV "drive out demons". ${ }^{0}$ Drive out artinya: mengusir, mengeluarkan. ${ }^{71}$ Sedangkan kata demons memiliki pengertian: setan-setan. Iblis-iblis, jin-jin. ${ }^{72}$ Dalam terjemahan bahasa Yunani daimo, nia evkba, llete ${ }^{73}$ kata daimo, nia dari kata daimo, nia yang berarti: roh jahat, dewa. ${ }^{74}$ Karena berbentuk plural, maka dapat dipahami bahwa roh jahat itu berjumlah lebih dari satu (banyak), sehingga lebih tepat memakai kata roh-roh jahat. Sedangkan kata evkba, l lete dari kata evkba, llw berarti: melemparkan keluar, mengusir, membawa keluar, menyuruh pergi, membawa, mengucilkan, menghina, memfitnah. ${ }^{75}$ Kata evkba, 1 lete berasal dari kata kerja orang kedua jamak aktif imperative. ${ }^{76}$ Dapat dimengerti bahwa para

\footnotetext{
66 Ibid., 409

${ }^{67}$ Hasan Susanto, Perjanjian Baru Interlinear......, Jilid I, 48

${ }^{68}$ Herbert Haag, Kamus Alkitab, (Flores: Nusa Indah, 1992), 241

69 Hasan Susanto, Perjanjian Baru Interlinear....., Jilid I, 48

${ }^{70}$ Ibid..., 48

${ }^{71}$ John M. Echols dan Hassan Shadily, Kamus Inggris Indonesia ..., 199

${ }^{72}$ Ibid., 173

${ }^{73}$ Hasan Susanto, Perjanjian Baru Interlinear....., Jilid I..., 48

${ }^{74}$ Hasan Susanto, Perjanjian Baru Interlinear....., Jilid II..., 480

75 Ibid., 256

${ }^{76}$ Hasan Susanto, Perjanjian Baru Interlinear....., Jilid I..., 48
} 
murid harus melakukan misi pengusiran setan itu segera sesudah Yesus memerintahkannya dan dilakukan terus-menerus dalam waktu pelayan ke depan. Penjangklauan misi para murid berdasarkan misi Yesus ialah pelepasan dari kuasa setan-setan.

\section{Sikap dan motivasi para murid sebagai agen tunggal misi Yesus (ayat 8b) \\ Sikap dan motivasi yang Yesus ajarkan kepada para murid sebagai} agen tunggal misi Yesus ialah dalam frasa "kamu telah memperolehnya dengan cuma-cuma, karena itu berikanlah juga dengan cuma-cuma". ${ }^{77}$ Kata dengan cuma-cuma dalam bahasa Yunani dwrea. n yang berarti: dengan cuma-cuma, tanpa alasan, dengan sia-sia. ${ }^{78}$ Sedangkan kata evla, bete dari kata dasar lambanw yang berarti: mengambil, menerima, memegang, membawa. Memikul, mengenakan, memiliki, beroleh. ${ }^{79}$ Kata evla, bete berbentuk kata kerja orang kedua jamak aorist aktif indikstif. ${ }^{80}$ Artinya bahwa para murid telah benar-benar memperolehnya, sudah dimiliki dengan gratis. Yang mereka peroleh ialah: panggilan sebagai kepercayaan bermisi, kuasa sebagai kemampuan bermisi, pengutusan sebagai kelayakan dan keabsahan bermisi dan arahan, petunjuk sebagai pedoman dan strategi bermisi. Hal tersebut juga dapat mengacu kepada semua yang telah diterima oleh para murid selama bersama Yesus. Kata "berikanlah" yaitu do, te dari kata dasar dido, tmi yang berarti: memberikan, membagi-bagikan, mengurbankan, ${ }^{81}$ dari kata kerja orang kedua jamak aorist aktif imperative. ${ }^{82}$ Yesus telah memerintahkan para murid untuk melakukan pelayanan misi dengan penuh pengurbanan bukan mencari keuntungan. Sikap dan motivasi misi para murid berdasarkan misi Yesus ialah misi yang rela berkurban.

\section{Objek pelayanan misi Yesus kepada para murid (ayat 6)}

Frasa yang menyatakan objek misi Yesus kepada para murid dapat dimengerti dari frasa "domba-domba yang hilang dari umat Israel" dalam

\footnotetext{
${ }^{77}$ Ibid..., 48

${ }^{78}$ Hasan Susanto, Perjanjian Baru Interlinear....., Jilid II..., 231

${ }^{79}$ Ibid..., 477

80 Hasan Susanto, Perjanjian Baru Interlinear....., Jilid I..., 48

${ }^{81}$ Hasan Susanto, Perjanjian Baru Interlinear....., Jilid II..., 206

${ }^{82}$ Hasan Susanto, Perjanjian Baru Interlinear....., Jilid I..., 48
} 
terjemahan baru Lembaga Alkitab Indonesia (LAI). ${ }^{83}$ Dalam terjemahan NIV memakai kata "rather to the lost sheep of Israel". ${ }^{84}$ Sedangkan dalam terjemahan bahsa Yunani pro,bata ta. avpolwlo, ta oi;kou VIsrah, $1 \AA^{85}$ kata tersesat (avpolwlo, ta) dari kata dasar avpollumi yang memiliki arti: membinasakan, membunuh, mati, menuju kebinasaan, kehilangan, rusak, terbuang, tersesat. ${ }^{86}$ Kata avpolwlo, ta (berbentuk kata kerja perfek aktif partisip maskulin plural akusiatif), ${ }^{87}$ artinya orang-orang Israel yang dianalogikan dengan domba berada dalam keadaan tersesat jauh dari Tuhan, sebagai akibat dari kehidupan mereka yang telah menjauh dari Tuhan. Dalam konteks ini, misi Yesus secara khusus dialamatkan kepada orang-orang Israel yang belum percaya. Namun dalam keseluruhan kitab Matius dapat dilihat bahwa sesungguhnya misi Yesus bukan hanya menjangkau orang Israel tetapi juga menjangkau semua orang di luar bangsa Israel (band. Matius 28:19-20). Dengan demikian, semakin jelas bahwa misi Yesus bersifat universal. Oleh karena itu objek misi para murid harus bersifat universal sebagaimana misi Yesus yang universal.

\section{Tindakan para murid terhadap Kebutuhan pelayanan misi (ayat 9 dan 10)}

Dalam terjemahan baru Lembaga Alkitab Indonesia (LAI) menuliskan bahwa para murid dilarang oleh Yesus membawa: emas, perak, tembaga, bekal, baju dua helei, kasut dan tongkat. ${ }^{88}$ Sedangkan dalam terjemahan bahasa Indonesia sehari-hari (BIS) dan juga dari terjemahan bahasa Yunani lebih memperjelas lagi bahwa yang dimaksud dengan emas, perak, tembaga itu ialah uang yang terbuat dari emas, perak, tembaga. ${ }^{89}$ Larangan itu

\footnotetext{
${ }^{83}$ Ibid.

${ }^{84}$ Ibid.

85 Ibid.

${ }^{86}$ Hasan Susanto, Perjanjian Baru Interlinear, Yunani-Indonesia dan Konkordansi (PBIK) Jilid II..., 102

87 Hasan Susanto, Perjanjian Baru Interlinear, Yunani-Indonesia dan Konkordansi (PBIK) Jilid I..., 48

88 Hasan Susanto, Perjanjian Baru Interlinear, Yunani-Indonesia dan Konkordansi (PBIK) Jilid I..., 48

89 Ibid.
} 
nampak dalam frasa "janganlah", 90 Janganlah dalam bahasa Yunani Mh yang berarti: tidak, jangan, supaya jangan, apakah mungkin, jangan lagi. ${ }^{91}$ Kata $\mathrm{Mh}$ merupakan kata partisip negative. ${ }^{92}$ Para murid tidak boleh membawa bekal selama mereka pelayanan misi dalam konteks teks Matius 10:1-15. Sedangkan kata membawa dalam terjemahan NIV "take" yang berarti: mengambil, menerima, memerlukan, membawa, menggunakan, melakukan. ${ }^{93}$ Dalam bahasa Yunani kth, shsqe dari kata dasar ktsomai yang berarti: memperoleh. ${ }^{94}$ Kata kth, shsqe berbentuk kata kerja orang kedua jamak aorist middle subjunctive. ${ }^{95}$ Yesus telah mengajak para murid untuk tidak membawa uang, baju lebih dari dua, bekal, kasut dan tongkat. Yesus mengerti bahwa para murid tentu memerlukan kebutuhan pelayan misi, tetapi Yesus mau membawa mereka pada suatu pemahaman yang benar mengenai kebutuhan pelayan misi, hal itu nampak dalam frasa "sebab seorang pekerja patut mendapat upah". Upah dalam bahasa Yunani trofh/j96 dari kata dasar trofh yang berarti makanan. ${ }^{97}$ Dapat dimengerti bahwa yang harus menjadi fokus dan prioritas para murid ialah pelayanan misi, bukan kebutuhan. Kebutuhan akan dicukupi oleh Tuhan, Ia memperhitungkan jerih lelah dan kebutuhan para misionari-Nya.

\section{Wilayah pelayanan misi (ayat 11)}

Yang mengungkapkan wilayah pelayanan misi dalam pengajaran Yesus kepada para muird nampak dalam frasa "apabila kamu masuk kota atau desa" terjamahan baru Lembaga Alkitab Indonesia (LAI). ${ }^{98}$ Dalam terjemahan NIV "whatever town or village you enter". 99 Whatever artinya: apa saja, apapun. ${ }^{100}$

\footnotetext{
${ }^{90}$ Ibid.

${ }^{91}$ Hasan Susanto, Perjanjian Baru Interlinear, Yunani-Indonesia dan Konkordansi (PBIK) Jilid I..., 517

${ }^{92}$ Hasan Susanto, Perjanjian Baru Interlinear, Yunani-Indonesia dan Konkordansi (PBIK) Jilid I..., 48

93 Hasan Susanto, Perjanjian Baru Interlinear....., Jilid I..., 48

${ }^{94}$ Ibid, 466

95 Ibid, 48

96 Ibid, 49

97 Ibid, 765

${ }^{98}$ Ibid, 48

${ }^{99}$ Ibid, 49

100 John M. Echols dan Hassan Shadily, Kamus Inggris Indonesia ..., 644
} 
Town artinya:kota ${ }^{101}$ dan village artinya: desa, dusun, kampung. ${ }^{102}$ Sedangkan dalam terjemahan bahasa Yunani eivj $h] n$ dV a'n po,lin $h^{\prime}$ $\mathrm{kw}, \mathrm{mhn}^{103}$ kata $\left.\mathrm{h}\right] \mathrm{n}$ berarti: apa saja. ${ }^{104}$ Kata $\left.\mathrm{h}\right] \mathrm{n}$ berbentuk kata ganti (pronoun) relative feminism singular akusiatif. ${ }^{105}$ Kata po, lin dari kata dasar po, lij yang berarti: kota (penduduk) kota. ${ }^{106}$ Sedangkan kata kw, mhn dari kata dasar $\mathrm{kw}$, mh yang artinya: desa, penduduk desa. ${ }^{107}$ Jika dipahami dari bentuk kasus kata $h] \mathrm{n}$ memang Yesus tidak mewajibkan para murid untuk pelayanan di kota atau desa, karena bersifat relative tidak mutlak berlaku untuk semua orang/tempat. Tetapi setidaknya lewat pengajaran Yesus pada waktu mengutus para murid dalam Matius 10:1-15 nampak adanya penjangkauan misi kepada penduduk di kota dan desa. Dapat juga dipahami bahwa bukan masalah tempat yang menjadi prioritas, tetapi orang yang tersesat (jiwa yang belum diselamatkan) yang berdomisili di kota atau desa. Maka sebenarnya melakukan pelayanan misi harus secara holistic baik dari segi geografis (wilayah), maupun strategi, metode dan jenis pelayanan, misi tidak hanya difokuskan pada daerah perkotaan atau pedesaan saja. Keberadaan orang terabaikan ada di kota maupun desa (yang miskin, pemulung).

\section{Strategi pelayanan misi (ayat 1112 dan 13) carilah, tinggallah, berilah.}

Strategi misi Yesus sebagai instruktur misi kepada para murid dapat dipahami dari frasa: "carilah orang yang layak untuk tinggal" (ayat 11), "masuk rumah dan berilah salam" (ayat 12). ${ }^{108}$ Kata carilah dalam bahasa Yunani evxeta, sate dari kata dasar evxeta, zw yang berarti: menyelidiki, bertanya, menanyai. ${ }^{109}$ Kata evxeta, sate dalam bentuk kata

\footnotetext{
${ }^{101}$ Ibid ,599

102 Ibid., 630

${ }^{103}$ Hasan Susanto, Perjanjian Baru Interlinear....., 49

${ }^{104}$ Ibid, 49

105 Hasan Susanto, Perjanjian Baru Interlinear....., Jilid I..., 49

${ }^{106}$ Hasan Susanto, Perjanjian Baru Interlinear....., Jilid II..., 657

${ }^{107}$ Ibid., 475

${ }^{108}$ Hasan Susanto, Perjanjian Baru Interlinear....., Jilid I..., 48

${ }^{109}$ Ibid, 288
} 
kerja orang kedua jamak aorist imperative. ${ }^{110}$ Artinya Yesus telah memerintahkan para murid untuk melakukan pendekatan misi lewat kehidupan sosial masyarakat, dengan mencari orang yang layak, yang mau menerima mereka untuk menginap di rumahnya. Sedangkan kata berilah salam, dalam bahasa Yunani avspa, sasqe dari kata dasar avspa, zomai yang berarti: memberi salam kepada, meminta diri, memberi hormat, menyambut, merasa berharga, mengucapkan selamat. ${ }^{111}$ Kata avspa, sasqe dalam bentuk kata kerja orang kedua jamak aorist middle imperative. ${ }^{12}$ Artinya Yesus telah memerintahkan para murid supaya menerapkan pendekatan misi etika kehidupan sosial masyarakat, dengan memberi salam dan hormat tatkala masuk ke rumah orang lain.

\section{Sikap terhadap penolakan dalam pelayanan misi (ayat 14)}

Bagaimana para murid harus bersikap tatkala menghadapi penolakan dalam pelayanan misi sudah diajarkan oleh Yesus seperti yang nampak dalam ayat 14 "apabila seseorang tidak menerima kamu dan tidak mendengar perkataan mu, keluarlah dan tinggalkanlah rumah atau kota itu dan kebaskanlah debu dari kaki mu". Ada dua langkah yang perlu dilakukan oleh para murid apabila ditolak, yaitu: tinggalkanlah, kebaskanlah. Kata tinggalkanlah dalam bahasa Yunani evxerco,menoi dari kata dasar evxerco, mai yang berarti: pergi ke luar, datang, pergi, berangkat, keluar turun, meninggal (dunia), menyebar, lenyap. ${ }^{113}$ Kata evxerco, menoi dari kata kerja presen middle participle maskulin jamak nominative. ${ }^{114}$ Artinya Yesus memerintahkan para murid untuk keluar dan pergi tinggalkan. Sedangkan kata evktina, xate dari kata dasar evktina, ssw yang berarti: mengebaskan (debu)-mengebaskan debu dari kaki sebagai tanda pemutusan hubungan. ${ }^{115}$ Kata evktina, xate berbentuk kata kerja orang kedua jamak aorist aktiv imperative. ${ }^{116}$ Artinya Yesus telah memerintahkan para murid untuk mengebaskan debu dari kaki mereka. Sikap terhadap

110 Ibid, 48

${ }^{111}$ Hasan Susanto, Perjanjian Baru Interlinear....., Jilid II, 124

112 Hasan Susanto, Perjanjian Baru Interlinear....., Jilid I..., 49

113 Ibid, 287

114 Ibid, 49

115 Ibid, 265

116 Ibid, 49 
penolakan misi dalam ajaran misi Yesus ialah pergi dan meninggalkan, indikasinya ialah tidak boleh melakukan perlawanan dan pemaksaan misi.

\section{Penghakiman terhadap para penolak misi (ayat 15)}

Penghukuman terhadap orang yang menolak misi Allah tertulis pada ayat 15: "sesungguhnya pada hari penghakiman tanah Sodom dan Gomora akan lebih ringan tanggungannya dari pada kota itu. Sedangkan dalam terjemahan bahasa Indonesia Sehari-hari (BIS) menuliskan: "pada hari kiamat, orang-orang kota Sodom dan Gomora akan lebih mudah diampuni Allah, dari pada orang-orang di Kota itu!". ${ }^{117}$ Frasa "penghakiman" dalam bahasa Yunani kri, sewj dari kata dasar kri, sij yang berarti: penghakiman, pengadilan, pengadilan (lokal), tuduhan, putusan, kuasa, menghakimi, dasar menghakimi, hukuman, keadilan. ${ }^{118}$ Jelas dalam pengajaran misi Yesus bahwa setiap orang yang menolak utusan misi Yesus akan dihakimi pada hari kiamat, dengan penghukuman yang sangat berat dan pasti. Menurut terjemahan Bahasa Indonesia Sehari-hari (BIS): “ingat! Pada hari kiamat, orang-orang kota Sodom dan Gomora, akan lebih mudah diampuni Allah dari pada orang-orang di kota ini!". Penghakiman dan penghukuman itu pasti dan serius, hal itu dapat dipahami dari penegasan Yesus dalam frasa: "Aku berkat kepada mu:.." menurut Terjemahan baru Lembaga Alkitab Indonesia (LAI). Sedangkan dalam terjemahan Bahasa Indonesia Sehari-hari, memakai kata "Ingatlah!" dan dalam terjemahan bahasa Yunani avmh. $n^{119}$ artinya: amin, sesungguhnya, sungguh-sungguh. ${ }^{120}$ Itu berarti bahwa apa yang dikatakan oleh Yesus adalah kebenaran.

\section{B. MISI GEREJA DALAM MENJALANKAN MISI ALLAH BERDASARKAN HAKEKAT MISI YESUS KEPADA PARA MURID}

\section{Dasar misi Gereja}

\footnotetext{
${ }^{117}$ Hasan Susanto, Perjanjian Baru Interlinear....., Jilid I..., 49

118 Ibid, 464

119 Ibid, 49

120 Ibid, 55
} 
Gereja dipanggil Allah untuk melaksanakan misi-Nya di tengah-tengah dunia ini. Gereja merupakan agen tunggal misi Yesus, sehingga seluruh kehidupan gereja seharusnya diresapi oleh beban misi. Pelayanan misi bukan merupakan pelayanan sampingan gereja. Oleh karena itu kekuatan pemahaman dan semangat kegerakan misi gereja sebagai agen tunggal misi Allah yang juga adalah misi Yesus, hanya berdasarkan pada hakekat misi Yesus yang juga adalah misi Allah. Pelayanan misi gereja tidak dapat dilepaskan dari Yesus sendiri yang memiliki peran utama dalam bermisi. Yesus-lah yang menjadi inisiator misi gereja, di mana misi gereja harus dilaksanakan sesuai dengan kehendak Tuhan Yesus. Selain itu gereja juga sangat bergantung pada kuasa Tuhan yang memampukan gereja-Nya bermisi. Tuhan Yesus memanggil gereja-Nya bukan untuk berpangku tangan, tetapi Yesus juga mengutus gerejaNya untuk pergi bermisi dengan petunjuk-petunjuk yang lengkap, yang harus dikerjakan oleh gereja. Sehingga pelayanan misi gereja memiliki arah yang jelas dan efektif.

\section{Tanggungjawab Gereja dalam Bermisi}

Gereja sebagai agen tunggal misi Yesus diperintahkan untuk pergi melaksanakan misi-Nya. Gereja tidak boleh berdiam diri dalam kenyamanan menikmati berkat-berkat Tuhan, namun gereja harus bergerak dan memikul tanggungjawab misi yang Tuhan Yesus embankan kepada gereja. Inti pemberitaan gereja dalam bermisi adalah Kerajaan Allah yang terimplementasi dalam pelayanan penyembuhan orang "sakit", yaitu yang lemah/ tidak berdaya (termasuk dalam pengertian ekonomi, rasa takut, moral, atau agama), juga yang menderita penyakit. Pelayanan misi gereja haruslah bersifat holistic, mencakup seluruh aspek kehidupan manusia (jasmani dan rohani). Selain itu, kerajaan Allah juga diimplementasikan melalui pelayanan Kebangunan Rohani (membangkitkan orang yang mati secara rohani). Gereja juga terpanggil untuk mentahirkan orang-orang yang dianggap najis, yang termarjinalkan dari tengah masyarakat serta melakukan pelayanan pengusiran roh-roh jahat, iblis, setansetan yang merasuk dan merusak bahkan menghancurkan hidup ataupun masa depan manusia.

\section{Sikap dan motivasi gereja sebagai agen tunggal misi Yesus}


Gereja dipanggil, diberi otoritas/kuasa dan diutus sebagai agen misi tunggal Allah berdasarkan kasih karunia Allah, bukan karena kelayakan gereja. Karena itu, motivasi gereja dalam melaksanakan misi harus benar, bukan untuk mencari kebesaran namanya sendiri, bukan pula mencari keuntungan berupa harta kekayaan. Yesus justru memerintahkan gereja-Nya untuk melakukan pelayanan misi dengan penuh pengurbanan bukan mencari keuntungan. Sikap dan motivasi misi gereja berdasarkan misi Yesus ialah misi yang rela berkurban.

\section{Objek pelayanan misi Gereja}

Pelayanan misi gereja harus memiliki sasaran yang tepat sesuai dengan yang Tuhan Yesus maksudkan. Obyek misi gereja bersifat universal. Misi gereja bukan hanya kepada golongan tertentu, melainkan kepada semua orang yang berada dalam keadaan tersesat, orang-orang yang jauh karena menjauhkan diri dari Tuhan, termasuk kepada orang yang mengaku Kristen tetapi belum menerima Tuhan Yesus sebagai juruselamat pribadinya. Selain itu, gereja juga harus menjangkau orang yang jauh dari Tuhan karena mereka tidak mengenal Tuhan yang telah menciptakan mereka dan yang berotoritas atas hidup mereka.

\section{Tindakan Gereja terhadap Kebutuhan pelayanan misi}

Yesus menghendaki gerejanya tidak terikat atau tidak bergantung kepada materi dalam melaksanakan pelayanan misi. Tuhan Yesus sangat memahami bahwa pelayanan misi gereja memiliki kebutuhan yang diperlukan untuk pelayanan misi, namun Tuhan menghendaki gereja memilki focus dalam bermisi, yaitu menjangkau jiwa-jiwa yang tersesat. Tuhan Yesus pasti akan mecukupkan kebutuhan pelayanan misi karena Tuhan juga menyediakan upah bagi gereja yang bermisi. Dengan demikian keterbatasan materi tidak boleh menjadi alasan bagi gereja untuk tidak bermisi.

\section{Wilayah pelayanan misi gereja}

Pelayanan misi gereja memiliki jangkauan yang sangat luas, yaitu di daerah perkotaan dan pedesaan, karena wilayah hunian manusia adalah kotakota dan desa-desa. Namun penekanan dalam pelayanan misi bukan pada wilayah, namun pada manusia yang menjadi penghuni wilayah tersebut (kota 
atau desa). Oleh karena itu, gereja tidak boleh melakukan pengkotakan wilayah penjangkauan misi.

\section{Strategi pelayanan misi gereja}

Gereja perlu memiliki strategi dalam pelayanan misi, karena strategi misi sangat mempengaruhi efektifitas pelayanan misi gereja. Tentu banyak strategi dalam pengajaran misi Yesus bahwa setiap orang yang menolak utusan misi Yesus akan dihakimi pada hari kiamat, dengan penghukuman yang pasti. Menurut terjemahan Bahasa Indonesia Sehari-hari (BIS): "ingat! Pada hari kiamat, orang-orang kota Sodom danGomora, akan lebih mudah diampuni Allah dari pada orang-orang di kota ini!'. Penghakiman dan penghukuman itu pasti dan serius, hal itu dapat dipahami dari penegasan Yesus dalam frasa : "Aku berkat kepada mu..." menurut Terjemahan baru Lembaga Alkitab Indonesia (LAI). Sedangkan dalam terjemahan Bahasa Indonesia Sehari-hari, memakai kata "Ingatlah!" dan dalam terjemahan bahasa Yunani avmh. $n^{121}$ artinya: amin, sesungguhnya, sungguh-sungguh. ${ }^{122}$

Adapun strategi misi yang dapat dilakukan oleh gereja adalah pendekatan misi melalui kehidupan sosial masyarakat, dengan mencari orang yang layak, yang mau menerima mereka untuk menginap di rumahnya. Pendekatan misi ini dapat disebut pendekatan misi etika kehidupan sosial masyarakat.

\section{Sikap gereja terhadap penolakan dalam pelayanan misi}

Keseriusan gereja dalam melaksanakan pelayanan misi bukan tanpa resiko. Resiko penolakan dalam pelayanan misi telah diingatkan oleh Tuhan Yesus pada saat mengutus para murid-Nya. Hal ini menjadi peringatan kepada gereja bahwa akan ada resiko penolakan yang akan diterima oleh gereja dalam menjalankan pelayanan misi. Dalam menyikapi penolakan tersebut, gereja harus mengambil tindakan yang tepat sebagimana yang telah diajarkan Tuhan Yesus kepada para murid-Nya, yakni meninggalkan orang yang menolak tanpa melakukan perdebatan, perlawanan dan pemaksaan misi kepada orang tersebut.

\section{Penghakiman terhadap para penolak misi}

\footnotetext{
${ }^{121}$ Hasan Susanto, Perjanjian Baru Interlinear....., Jilid I..., 49

122 Ibid, 55
} 
Dalam pelayanan misi, gereja tidak boleh gentar dan tawar hati apabila ditolak karena setiap orang yang menolak utusan misi Yesus akan dihakimi pada hari kiamat, dengan penghukuman yang pasti dan serius. Oleh karena itu gereja atau utusan misi tidak perlu menghakimi para penolak misi karena penghakiman adalah hak Allah. Di samping itu, hal ini menjadi penghiburan bagi gereja dan setiap utusan misi, tatkala menghadapi penolakan. Maka gereja dan para utusan misi harus tetap bersemangat dan terus maju dalam pekerjaan misi, sekalipun ada penolakan berupa penganiayaan bahkan ancaman kematian sebagaimana perkataan Tertulianus yang seringkali dikutip oleh orang percaya bahwa "darah martir adalah benih gereja".

\section{KEPUSTAKAAN}

Douglas, J. D.,

2005 Ensiklopedia Alkitab Masa Kini, Jakarta: Yayasan Komunikasi Bina Kasih.

Echols, John M. dan Hassan Shadily

1997 Kamus Inggris Indonesia, Jakarta: Gramedia.

Haag, Herbert

1992 Kamus Alkitab, Flores: Nusa Indah.

Hakh, Samuel Benyamin

2008 Pemberitaan Tentang Yesus Menurut Injil-Injil Sinoptik, Bandung: Jurnal Info Media.

Pasaribu, Marulak

$\mathrm{Tt} \quad$ Injil Sinoptik, Batu: Departemen Literatur YPPII

Susanto, Hasan

2006 Perjanjian Baru Interlinear, Yunani-Indonesia dan Konkordansi (PBIK) Jilid I \& II, Jakarta: Lembaga Alkitab Indonesia.

Tulluan, Ola

Tt Introduksi Perjanjian Baru, Batu: Departemen Literatur YPPII

Vine, W.E.,

1996 Vines Complete Expository Dictionary, Amerika: Thomas

Nelson Publishers 